\title{
Identifying Stakeholders in Land Use Management Process and Its Critical Factors in ASEAN ${ }^{1}$
}

\section{Tulus Tahi Hamonangan Tambunan}

Center for Industry, SME and Business Competition Studies, University of Trisakti, Jakarta, Indonesia

\section{Email address:}

ttambunan56@yahoo.com

\section{To cite this article:}

Tulus Tahi Hamonangan Tambunan. Identifying Stakeholders in Land Use Management Process and Its Critical Factors in ASEAN. Journal of Investment and Management. Vol. 4, No. 5, 2015, pp. 237-249. doi: 10.11648/j.jim.20150405.24

\begin{abstract}
The main aim of this qualitative-based research is two folds: to identify the main stakeholders who are directly and indirectly impacted by land and who have actually or potentially influence on land use management (LUM) and the critical factors which determine the smooth coordination and cooperation among stakeholders in member countries of the Association of Southeast Asian Nations (ASEAN). Through reviewing available key literature in individual ASEAN member states (AMSs), it shows that at the macro (aggregate)-level, there are three key stakeholders in LUM, i.e. government, companies, and community. Whereas, at the micro (disaggregate)-level, there can be a large number of stakeholders. With respect to government, many department or agencies may involve in LUM. One important finding of this study is that individual villagers or farmers are not always easy to be integrated in the land use planning and LUM; while farmer groups should be the engine of this integration.
\end{abstract}

Keywords: LUM, ASEAN, Indonesia, Thailand, Philippines, Cambodia, Lao PDR, Malaysia, Vietnam

\section{Introduction}

Total population in ASEAN is growing every year, and so demand for food is also growing. This means that every year farmers in ASEAN member states (AMS) (except Singapore) will need to produce more and more food from land which continues to decline because of population growth, rapid industrialization and urbanisation. As a result, land conflicts, which are disagreements and disputes over access to, and control and use of land often emerge because people have different uses for land, or want to manage them in different ways. In Indonesia, for instance, land conflicts between basic food (especially rice) farmers and plantation owners who are mainly big export-oriented companies on one hand, and between rice farmers and real estate and highway developers have been intensified in the past one decade. The fact is that farmers as the key stakeholder in land use management (LUM) are always the victim of the conflict. But, this is not only happened in Indonesia. Land conflicts are often occurred in other AMS as well especially in countries where military influence is still strong, such as Cambodia, Lao PDR,

\footnotetext{
${ }^{1}$ This study could not have been undertaken without the generous support of the 2013-14 Senior Scholar Fellowship Programme under the 2012-2015 ASEANCanada Research Partnership.
}

and Viet Nam, and where law enforcement is weak and corruption is in all levels of government administration such as the Philippines (Albano, 2003; Brits, et al, 2002; Davuth, et al.,2008; Dealca, 20091 Ducourtieux, at al., 2005; and Natalie and Pred, 2009).

Based on the above current situation, this qualitative-based research aims to answer the following two research questions First, how many stakeholders that have influence on LUM? Second, what are the critical factors which determine the smooth process of coordination and cooperation between stakeholders? The importance of the first question is due to the fact that there are either too many stakeholders (i.e. those who are directly as well as indirectly affected and those whose "interests" determine them as stakeholders), or not clear who have the right to use or manage land (e.g. FAO, 2000; IFC, 2007). Most conflicts are characterized by the presence of too many or multiple stakeholders who themselves may have subgroups with varying interests. Disagreements also arise when these interests and needs are incompatible, or when the priorities of some user groups are not considered in policies, programs and projects (FAO, 2000). Certainly, if these conflicts are not well addressed can escalate into violence, cause environmental degradation, disrupt projects and undermine livelihoods.

The importance of the second question is due to the fact 
that LUM issue is inherently complex as it involves not only many stakeholders with different needs for land, different interests on land use, different behaviours, different knowledges related to LUM, and differences in other backgrounds, but it also involves many physical factors such as the ecological cycles, hydrological cycles, climate, animals, plants and geography etc., and non-physical factors including land title security, laws, political system, and socioeconomic as well as institutional factors, which vary by individual AMS. In other words, a good LUM based on coordination and cooperation of stakeholders will not happen if all these factors are not in favour of it. All these factors are dynamic and many of them are inter-related. A change in one of them may have far reaching and/or long term impacts which may even be irreversible. So, having good knowledge on critical factors in determining a good coordination and cooperation among all parties involved or impacted by land use is crucial.

\section{Analytical Approach and Conceptual Framework}

To answer these questions, this study adopts stakeholder analysis approach, as it is suggested generally in the literature as an appropriate (if not the best) approach for natural resources management (NRM) including LUM. According to many, e.g. Allen and Kilvington (2001) (quoted from Abdulharis, et al, 2008), and Billgrena and Holme (2008), stakeholder analysis is the identification of stakeholders that may have influence directly as well as indirectly on LUM, an assessment of their interests, and the ways in which those interests affect project riskiness and viability

In its published Stakeholder Engagement: A Good Practice Handbook for Companies Doing Business in Emerging Markets, IFC (2007) gives the main reason why the stakeholder is more suitable than other approaches for a good risk management, including in natural resources management (NRM), namely as a means of describing a broader, more inclusive, and continuous process between land or natural resources (NR) using company and those potentially impacted that encompasses a range of activities and approaches, and spans the entire life of a project. Especially when there are many stakeholders, in which the company is not necessary to engage with all stakeholders with the same level of intensity all of the time, the company needs to be strategic and clear as to whom it is engaging with and why it is crucial. In this practical handbook it is stated clearly that the land or NR-using companies should prioritize their stakeholders and, depending on who the stakeholders are and what interests they might have, figure out the most appropriate ways to engage. Stakeholder analysis therefore assists in this prioritization by assessing the significance of the project to each stakeholder group from their perspective, and vice versa.

With respect to land use, this concept provides a basis on designing a sustainable LUM system by identifying different affected groups, well known as stakeholders (e.g. local communities including farmers, local government authorities, non-governmental and other civil society organizations, local institutions and other interested or affected parties), and their the goals and roles, and by helping to formulate appropriate forms of engagement with these groups. The stakeholders approach gives better insight about the degree of complexity of NRM or LUM. The more number of persons or groups engaged, who are directly or indirectly affected by land use or a project, as well as those who may have interests in a project and/or the ability to influence its outcome, either positively or negatively, the higher is the expected degree of complexity. But, on the other hand, if their goals and roles can be identified, and ranges of activities and interactions among them can be established, the risk of NRM or LUM can be minimized. The risk is not only in the form of production failure, actual revenues are less than expected or should be, total costs higher than revenues, or soil degradation, but also in the form of conflicts. Conflicts can occur because planners and managers identify stakeholders inadequately, or they refuse to acknowledge a group's interest in a resource. When planners and managers fail to identify and consult with the full spectrum of stakeholders, they limit their understanding of these groups' diverse needs and priorities and their indigenous knowledge of the situation. This increases the likelihood of conflicts emerging (FAO, 2000).

With so many stakeholder, it is of course not practical, and usually not necessary, to engage with all stakeholders with the same level of intensity all of the time. Therefore, being strategic and clear as to whom the land-using company is engaging with and why is crucial, as this strategy, can help the company to save both time and money. IFC (2007) in its practical handbook for companies to engage effectively and efficiently with their projects-related stakeholders, state clearly that the land or natural resource-using companies should prioritize their stakeholders and, depending on who the stakeholders are and what interests they might have, figure out the most appropriate ways to engage. For example, some stakeholders will be more affected by a particular phase of a project, such as construction activities, while others will be impacted by the implementation of the project, e.g. production processes.

According to the handbook, when prioritizing or selecting stakeholders by degree of importance or level of engagement, the following questions are important:

1) What type of stakeholder engagement is mandated by law or other requirements?

2) Who are the most vulnerable among the potentially impacted parties, and are special engagement efforts necessary?

3) At which stage of project development will stakeholders be most affected (e.g. procurement, construction, operations, decommissioning)?

4) What are the various interests of project stakeholders and what influence might this have on the project? 
5) Which stakeholders might help to enhance the project design or reduce project costs?

6) Which stakeholders can best assist with the early scoping of issues and impacts?

7) Who strongly supports or opposes the changes that the project will bring and why?

8) Whose opposition could be detrimental to the success of the project?

9) Who is critical to engage with first, and why?

10) What is the optimal sequence of engagement?

In stakeholder theory literature, the question of who is, and who is not, a stakeholder has long been a point of debate. The critical question here is: should stakeholder status be reserved for constituencies that have a very close relationship with the company? Or, should stakeholder status be broadly interpreted and take into account all of people or parties that can affect, and be affected by, the company? According to the literature, at the minimum, stakeholders are those groups or people or parties from whom the company has voluntary accepted benefits and to whom the company has therefore incurred obligations of fairness. Typically, this includes groups such as financiers, employees, customer, suppliers, and local communities. Stakeholder theory maintains that normative or legitimate stakeholders are owned an obligation by the company, while derivative stakeholders hold power over the company and may exert either a beneficial or harmful influence on it (e.g. Phillips, 2004).

Thus, according to this theory, in the case of LUM, the legitimate stakeholders are including farmers, local communities, direct related government department/agency, suppliers, financiers. While, other groups such as environment activists or local NGO providing trainings or technical assistances to local farmers are not normative or legitimate stakeholders, but the land-using company may choose to care for the environment and welfare of local farmers because its legitimate stakeholders (e.g. customer) may care deeply about it.

However, given time and financial limitations, this study is fully based on a literature review consisting key case studies in ASEAN member states (except Singapore). There is a number of good case studies which adopt stakeholder analytical approaches based on field investigations. They include case studies ever done more than one decade ago (and no new studies after their period can be found) by Grimble and Wellard (1997), and Grimble (1998) on some Asian countries e.g. Nepal, Indonesia and Koreas' community forestry. Those case studies show successful examples of how stakeholder analysis can be incorporated into the NRM. This allowed the stakeholders to identify their needs and level of involvement with the forests.

\section{The Study}

\subsection{Land Use Management}

LUM is the process of managing the use and development of land, covering the debate about norms and visions driving the policy-making and sector-based planning both in the strategic and operative time spans, as well as the spatial integration of sectoral issues, decision-making, budgeting, participation, implementation of plans and decisions and the monitoring of results and evaluation impacts. LUM is driven by various decisions taken at different levels (local, regional, national) and in different sectors (public, private, civil society). It is a continuing process which improves the coordination of regional development policy as well as public investments and public-private investments and the involvement of inhabitants and local stakeholders in common visions. Sustainable LUM acts in a multi-level governance structure between an operational project level and a strategic level of region (urban and/or rural) management. Therefore, land use planning as an instrument of LUM or rather a tool to reach the broader aim of sustainable land development is concerned with the formulation of policies and plans on the use and development of land (Engelke and Biehl, 2010).

LUM in general is not an easy task as it is challenged by a diversity of issues including demography, politic, cultural, ethnic and religious diversity, economics, environment, climate and geography. There are also structural factors that play a role in the process of LUM, e.g. location, the physical infrastructure, different levels of government agencies namely central government (e.g. Ministry of Forestry, Ministry of Agriculture, Ministry of Industry, Ministry of Trade, Ministry of Environment, Ministry of Finance) versus regional or local government agencies, competition between agencies in authority. Also are functional factors which include political issues inherent in the special interests of the different stakeholders that influence understanding of those diverse issues and factors that impact the process.

At the macro (aggregate)-level, there are three key stakeholders in LUM, i.e. government, companies, and community. Government has a role in i) develop and establish law, regulation, guideline and socialization, ii) guidance and surveillance, and iii) administration and law enforcement. Corporate/company/operator has a role in: i) preventing and controlling pollution to environment, ii) monitoring and reporting, iii) provide information/report that correct, accurate, and right, and iv) manage, recover and rehabilitate pollution of environment. Community has a role in: i) giving a recommendation/idea, ii) social control, iii) giving report and complain on the occasion pollution on environment that harmful for community.

At the micro (disaggregate)-level, there can be a large number of stakeholders. With respect to government, many department or agencies may involve in LUM. With respect to companies, there can be more than one company holding/using the same land. Whereas, with respect to community, it comprises of many individuals or households, not only individual farmers or herders or growers but also other villagers with different natural needs of land. Unfortunately, these individual villagers or farmers are not always easy to be integrated in the land use planning and LUM; while farmer groups should be the engine of this integration. 
With such many stakeholders who may have conflicting views about the best land management practices to achieve sustainable land management, conflicts sometimes cannot be prevented. Therefore, knowing behavior of stakeholders regarding land use on a case by case basis is important which leads to a sector view on land use by the different stakeholders and their requirements and needs. It is indeed important to open up the stakeholders view to an integrative view on land use and coordinate and combine different sector requirements and needs on land use (Engelke and Biehl, 2010).

\subsection{Brief Overview of Land Policy and Administration in AMS}

a) Indonesia

The importance of the colonial influence on the development of land tenure systems in Asia cannot be overemphasized: in Cambodia and Lao PDR to the French, Indonesia to the Dutch and Japanese and the Philippines to the Spanish and Americans, Malaysia and Myanmar to the British.. In Indonesia the strong colonial influence resulted in land laws becoming a dualism between western systems and customary systems, with elements of the latter being incorporated into the former. Today the customary elements incorporated into the new systems continue to feature strongly (Brits et al., 2002). In Indonesia, the Basic Agrarian Law No. 5 of 1960 is based on adat or customary law; it provides the basis for land administration. An important change in regulations (the first amendment in 30 years) provided for a right to title after 20 years of occupancy 'in good faith', and a recognition of occupancy by the surrounding community (Brits et al., 2002)..

In other words, the Law should be seen as a key step in the implementation of the Constitution and providing a stronger basis for customary right protection. It confirmed the constitutional right of the State to control all unclaimed land and resources while recognizing customary rights under certain conditions (Articles 3 and 5). In fact, customary rights are applicable to lands not owned by the State, as long as they do not interfere with national interests or the common good. The validity of ulayat rights is strongly restricted by Article 5. The Law is compounded by land policies that have favoured land consolidation to facilitate investment, especially foreign direct investment, without resolving underlying conflicts over ownership and use rights. However, the Law has in many cases been ignored by related sectoral laws and policies governing forestry, environment, water, and mining, severely limiting management opportunities for small farmers and fishermen (Kayoi et al, 2006).

As in many other AMS (e.g. Thailand, Lao PDR, the Philippines), the land administration or registration in Indonesia is undertaken in all Municipality/Regency land offices. Regarding land tenure, Indonesian National Land Agency (BPN) to hold full control on delivering land tenureship and permits related to land use. Considering its wide-spread coverage, BPN is capable on performing this task. Considering full authority of Provincial and Municipal
Government due to Regional Governance Act, Provincial and Municipal Government could consult further arrangement in relation to permit granting on land use management to BPN (Abdulharis, at al., 2008).

\section{b) Cambodia}

There are 3 pillars of the land policy in Cambodia: (1) land administration: focusing on an effective land titling programs in systematic and sporadic, dispute resolution, land market orientation; (2) land management: focusing on sustainable development by e.g. developing of zoning, and land use planning; and (3) land distribution: designing to provide residential and farming land to the poor landless and land poor households (Davuth, et al., 2008). As the Ministry of Land Management, Urban Planning and Construction is the lead institution for land-related questions, it is therefore the main important stakeholder in land use management in the country.

However, despite the Cambodian government's efforts to have a good land management system, as in Indonesia, land conflicts are becoming a serious problem in Cambodia. Sokha, et.al. (2008) who studies land transaction in rural areas in Cambodia have found that the main type of land dispute has changed from disputes over boundaries to ownership rights. The land market has expanded and this has led to many cases of land disputes due to various reasons, which include unclear land rights before land transfers or sales; absence of demarcation between the state forest land and private, or community land; ignoring traditional rights of fallow land in shifting agriculture areas; illegal encroachment on forested land for selling; and overlapping of administrative boundaries.

Even, a report from the Cambodian Forestry Administration (FA, 2010) concludes that currently, insecure title over forested land and unclear rights to use de facto open access forest resources mitigate efforts to maintain the forest cover, to secure livelihoods or to contribute to rural economic growth in the country. According to the report, this situation reflects a lack of coherence in rural land management policies, weak capacities of sub-national sector line agency departments, poor service delivery mechanisms and the limited involvement of rural land and resource users in formalized NRM procedures.

\section{c) Lao PDR}

The Lao People's Democratic Republic (PDR) is a mountainous land-locked country with relatively low population density. Some 87 percent of its territory is upland, where there are high incidences of poverty and little infrastructure. Lao PDR is rich in wetland biodiversity and the least damaged ecosystems in Southeast Asia. Wetlands play a very important role in the lives of Lao people since the majority of the people live in the wetland-rich Mekong basin and rely on wetlands for their dairy subsistence and income generation. Besides, wetlands provide a diverse range of valuable services to society. But unsustainable NRM is beginning to reverse this situation caused by such as government policies, socio-economic change and population pressure (Sopha and Sharp, 2013). 
All land and forestland in Lao PDR is owned by the State, based on Forestry Law 2008. In Article 4 it is stated that natural forest and forest is the property of the national community. Customary rights are not acknowledged in this Law but only in minor Ministerial recommendations. But, it is able to grant certain rights of management, use and exploitation to different entities, with the form of rights dependent on the classification of land. The Law also dictates that a registered land title is the highest form of property right; analogous to ownership. A land title is the only legal document demonstrating permanent land use rights and grants the holder a variety of rights, such as to use the land as collateral, to transfer the land, and to give the land as inheritance. Such land titles can be granted to individuals or families on up to three hectares (Sipaseuth and Hunt, 2009).

Recently, Lao PDR has developed a new policy aiming for the sustainable land/forest management including through targets for increased national forest cover, namely the Forestry Strategy to the Year 2020. Two ministries are directly responsible for the success of this strategy, i.e. the Ministry of Agriculture and Forestry (MAF) and the Ministry of Natural Resources and Environment (MoNRE). Concurrently, management of the forestry sector more broadly was transferred from MAF to the Department of Forest Resource Management (DFRM) within MoNRE. (REDD, 2012).

\section{d) Malaysia}

The Federation of Malaysia comprises Peninsular Malaysia in the East and the states of Sabah and Sarawak on the island of Borneo (or Kalimantan) at the West side. In land administration contexts, the right of the individual to own land is safeguarded under the Federal Constitution, in which land is administered by the State Authority, although the Federal Government plays a very important role in legislating land matters (Samsudin, 2011).

These three parts of Malaysia are different in land administration. In peninsular Malaysia, which is a federation of states, each state is responsible for its own land issues. But, all states operate the Torrens system of registration, administered by the State District Office and coordinated by Director General of Lands and Mines of the State Department of Land and Mines (Samsudin, 2011). Land administration in Peninsular Malaysia is governed by the National Land Code 1965 (Act 56) which was created to provide a consolidated legislation in all aspects of land tenure and registration, land transfer, leases, charges, easement and other rights of alienation and development of land. In Sarawak, land is administrated by Land and Survey Department, headed by the Director of Lands and Surveys, under the State Ministry of Planning and Resource Management. Sarawak also operates the Torrens system of registration and its current land law is governed by the National Land Code Chapter 81, 1958. Land administration organizational structure in Sabah share almost the same structure as Sarawak, i.e. administrated by Lands and Surveys Department under the portfolio of the Chief Minister's Department through the office of the Secretary of
Natural Resources, and its current framework for land policy is provided by the Sabah Land Ordinance Chapter 68, 1930 (Samsudin, 2011).

\section{e) Myanmar}

The majority of its population lives in rural areas and depends on land as a primary means of livelihood. But, because all land in Myanmar ultimately belongs to the state, citizens and organizations do not own land; they depend upon use-rights, and tenure rights vary depending on the type of land involved. The country's laws grant women equal rights in some respects and also recognize certain customary laws that provide women equal rights in relation to land. In practice, however, the rights of many women are governed by customs that do not afford them equal access to or control over land (USAID, 2013).

Differently than in other AMS, Myanmar does not have a written policy on land use and land tenure. But, the country does have Farmland Law issued in March 2012, which defines rights and responsibilities relating to tenure and establishes a hierarchy of management over farmlands. The Farmland Law affirms that the state is the ultimate owner of all land and creates a private-use right that includes the right to sell, exchange, inherit, donate, lease and "pawn" farmland. It also establishes a system of registered land-use certificates. The law effectively replaces the 1963 Tenant Farming Law and the 1963 Protection of Peasants' Rights Law, and repeals the 1953 Land Nationalization Act, the Disposal of Tenancies Law and the Agriculturalist's Rights Projection Law. It also covers: conditions under which farmers can retain farmland use-rights; the state's power to rescind such rights; the process for settling certain land-related disputes; and basic requirements for compensation in the case the government acquires the land for public purposes (USAID, 2013).

f) The Philippines

Before 2003, Philippines had used almost 100-year old land administration system from the West that has been institutionalized across, and implemented by, different government agencies. As it is a very old system, not suitable anymore for the current condition of the country, especially with respect to the use of land, the system was found to have the following structural defects: (i) conflict among laws regulating the system and its administration; (ii) two processes for titling land (administrative and judicial processes); (iii) multiplicity in forms of ownership rights in land; (iv) multiplicity of property taxes and related disincentives to formalization of land transactions; (v) multiplicity in land valuation methods; and (vi) duplication and overlap in the roles, functions and activities of land administration agencies (Albano, 2003). In response to this problem, the government has undertaken an initiative undertaken to improve its land administration system, through the Land Administration and Management Project (LAMP). LAMP was conceptualized to respond to the weak and inefficient land administration system in the country which has eroded confidence and trust in the titling and registration system as a whole (Dealca, 2009). Then, in 2003, the government issued The Land Administration Reform Act 
of 2003, which is the new law on land administration in the Philippines (Albano, 2003).

g) Thailand

Thailand, although not colonized, borrowed extensively from the west in establishing its legal and administrative system. A titling system for private rights in land was introduced in 1901, based on the Australian system. As in other AMS like Indonesia, Lao PDR and the Philippines, title registration systems also operate in Thailand, but titles are not guaranteed by the state, not like for instance, in the Philippines.

The following five major pieces of legislation constitute the core of Thailand's land regulation and governance framework (USAID, 2013). First, Thailand's Constitution which provides that the state shall adopt land policies, including policies relating to land use, land distribution, town and country planning, and the sustainable protection of land and other natural resources. Second, the Land Code (LC) 1954, which is, as amended, Thailand's primary land legislation. The LC recognizes a range of land documents with the main ones are pre-emptive claims, which are nontransferable, and certificates of utilisation and titles, both or which are transferable and accepted as collateral (Brits et al., 2002). Third, the Agricultural Land Reform Act of 1975 that was enacted in an effort to address the high rate of tenancy in certain regions of the country, the large number of landless households, and the encroachment of public lands for cultivation. Fourth, the Land Development Act of 1983 which established a national Land Development Committee to help improve the utilization and productivity of the country's agricultural land. Fifth, the Land Readjustment Act of 2004, which governs processes for land re-plotting and development in order to improve land utilization.

As in many other AMS (e.g.. Indonesia, Lao PDR and the Philippines), the land administration systems in Thailand, are all decentralized. In Thailand the title register is maintained in the 16 Bangkok Metropolitan, 76 provincial and 272 branch land offices. Registers for the lesser documents in Thailand are maintained in the 758 district land offices (Brits et al., 2002).

Thai government has implemented a 20 year project 19842004, named the Land Titling Project (LTP) in four five year phases. The project is considered as one of the largest land titling programs implemented throughout the world, and it is recognized as having been very successful and has served as a model for other countries in the region (e.g. Indonesia, Lao PDR and the Philippines) and throughout the world (Brits et al., 2002).

Within ASEAN, Thailand has very efficient systematic land titling (first registration) procedures and has issued over 8.5 million titles since 1984 under the LTP). The procedures in Thailand have largely served as a model for systematic land titling in the region. Land titling is being undertaken in Indonesia and Lao PDR, with pilot land titling being undertaken in the Philippines and Cambodia (Brits et al., 2002).

h) Vietnam
Following the introduction of đổi mói reforms, a new Land Law was enacted in 1987, which ratified the ongoing decollectivization of agriculture and began to allocate agricultural land holdings of cooperatives to individual households based on family size. The second Land Law in 1993 granted five rights to land users, i.e. transfer, exchange, lease, inherit and mortgage, and extended lease terms to 20 years for annual crops and 50 years for perennial crops and forest land through the issuing of Land Use Rights Certificates (Wells-Dang, 2013). Further, in 1994 the government issued Decree $02 / \mathrm{CP}$ on allocation of forest land, followed in 1995 by Decree $01 / \mathrm{CP}$ on contracting of land for agriculture, forestry, and aquaculture purposes, and in 1999 Decree 163 on leasing of land for forestry purposes (Tan, 2011).

The political economy of land shifted once again after 2000 as Vietnam embarked on a new policy emphasizing "industrialization and modernization". The 2003 revision of the Land Law allowed the State to appropriate land for economic development purposes, also serving to legitimize previous practices of land appropriation (Wells-Dang, 2013). The new Land Law in 2003 is recognizing the legal status of village communities in land tenure, and in 2004 the government issued Forest Protection and Development Law which is recognizing legal status of village communities in forest management (Tan, 2011).

In recent years, land rights have become highly contested in Vietnam in recent years, as the economy has grown rapidly from a system of collectivized agriculture after 1975 to a mixed model of state and private management described as a "socialist-oriented market economy". Vietnam's land endowment is one of the lowest in the world: each agricultural household holds, on average, less than 0.5 hectare. The national priority on "industrialization and modernization" has placed new demands on agricultural and forest land for urban-industrial expansion. The high level of public concern over land tenure and its links to political and social stability have led to widespread calls for revision of the 2003 Land Law (Wells-Dang, 2013).

\subsection{Some Evidence on Main Stakeholders in LUM Processes and Their Critical Factors in ASEAN}

Based on limited case studies from selected AMS, the next table in a matrix form showing evidence on efforts to improve LUM through community-based/stakeholder approach. The fourth column shows key stakeholders that were currently involved in LUM, and the last column presents the critical factors that need to be solved (i.e. lacked supporting factors) for sustainable land management identified by the particular authors.

As can be seen in this table, in each cases many people or parties are considered as stakeholders. Although the authors do not make a distinction between legitimate and nonlegitimate stakeholders, in this table the stakeholders are grouped into these two categories. As can be seen from the all cases presented in the table, there are four key legitimate stakeholders in a LUM, namely farmers or land owners, 
companies or land users, local community, and government (central and regional/local). Whereas, the most important non-legitimate stakeholder reveals to be non-government organizations/NGOs, and in some cases donor organizations also involved as non-legitimate stakeholders, at least according to the definition adopted in the stakeholder theory literature.

Those stakeholders can also be distinguished into the followings: direct, indirect, and no impacted stakeholders. Direct impacted stakeholders are not only those whose revenues or income or welfare change (decline or increase) directly because of the land use: i.e. the land-using company, farmers and other local community/villagers (e.g. local transport owners, local suppliers, local traders, etc), but also those whose daily way of life will be disturbed because of production activities of the land-using company (i.e. local surrounding villagers). In other words, direct impacted stakeholders are the most vulnerable among the potentially impacted, and therefore special engagement efforts are necessary.

Indirect impacted stakeholders are those whose revenues will change (e.g. increase) because of activities of the landusing company, e.g. income or value added taxes payments to local and/or central government. But local business owners whose activities will be disturbed indirectly can also be considered as indirect impacted stakeholders. For instance, many agricultural laborers have lost their job because the land where they used to work in has been sold or rented to a company. Because of this, unemployment has increased which has a negative impact on local businesses such as shops, transport, services, food stalls, etc. Direct as well as indirect impacted stakeholders are included as legitimate stakeholders.

For those who are not impacted at all are considered as no impacted stakeholders. But they may have various interests of and therefore influences on activities of the company. This type of stakeholders includes activist groups, press people/media, NGOs, donor organizations, universities, etc. According to the stakeholder theory, they are considered as non-legitimate stakeholders from the company's perspective. Although, depending on type of project and hence type of its potential impacts and the degree of significance of the impacts, these groups are too important to be ignored at all by the company.

The table also shows that although the types of critical (lacked supporting) factors for having a good LUM vary by case, there are some common critical factors, and the most important ones that revealed from many cases are issues related to ownership (i.e. lack of customary or land owner's rights and system, security of land ownership, land tenure system), followed by lack of fully involvement of local communities in all aspects of LUM, and lack of coordination, either among government agencies or between government and other stakeholders or among other stakeholders, especially between farmers/land owners and land-using companies. While in some other cases, lack of data or information especially on potential stakeholders and their need, the real owners of land revealed as the most crucial factors.

With respect to the issues related to the land ownership or land tenure security, it seems that despite the efforts given by the governments in these countries to improve their land administration system by issuing laws and regulations, as discussed before, they have not yet managed to solve these problems. Two main factors may explain this, namely lack of law enforcement and corruption especially at the lower level of government administration (regional or local government).

Table 1. Efforts to improve LUM through community-based/stakeholder approach in individual AMSs.

\begin{tabular}{|c|c|c|c|c|c|}
\hline $\begin{array}{l}\text { Member } \\
\text { state }\end{array}$ & Region/area & Case & $\begin{array}{l}\text { Identified Main Legitimate and } \\
\text { Non-legitimate Stakeholders }\end{array}$ & Source & $\begin{array}{l}\text { Critical factors which need to be solved for } \\
\text { sustainable LUM }\end{array}$ \\
\hline Indonesia & Papua & $\begin{array}{l}\text { Tropical } \\
\text { forest } \\
\text { management }\end{array}$ & $\begin{array}{l}\text { Legitimate } \\
\text { (i) local communities/villagers } \\
\text { (including farmers, forest or land } \\
\text { resources dependent communities, } \\
\text { land owners) } \\
\text { (ii) land-using companies } \\
\text { (iii) central government (related } \\
\text { ministries and agencies) } \\
\text { (iv) provincial, and local (district) } \\
\text { government }\end{array}$ & $\begin{array}{l}\text { Kayoi et al } \\
(2006)\end{array}$ & $\begin{array}{l}\text {-Legal recognition to customary rights } \\
\text { (ongoing struggle between the provincial and } \\
\text { central governments over powers to regulate } \\
\text { customary rights) } \\
\text {-Availability of data on customary land } \\
\text {-Clear standards or procedures in place that } \\
\text { take adequate account of community land-use } \\
\text { systems } \\
\text {-Institutional mechanisms to guarantee the } \\
\text { transparent, fair, and equitable distribution of } \\
\text { funds and development support under } \\
\text { company-community agreements. } \\
\text {-Allocation of forest resources between } \\
\text { communities and large-scale commercial } \\
\text { concessionaires, including the allocation of } \\
\text { areas for direct community management, based } \\
\text { on participatory mapping of customary lands; } \\
\text {-Clearl definition of rights and responsibilities } \\
\text { with respect to compensation and community } \\
\text { development in areas assigned to external } \\
\text { investors; } \\
\text {-Local community and government } \\
\text { institutional support, }\end{array}$ \\
\hline
\end{tabular}




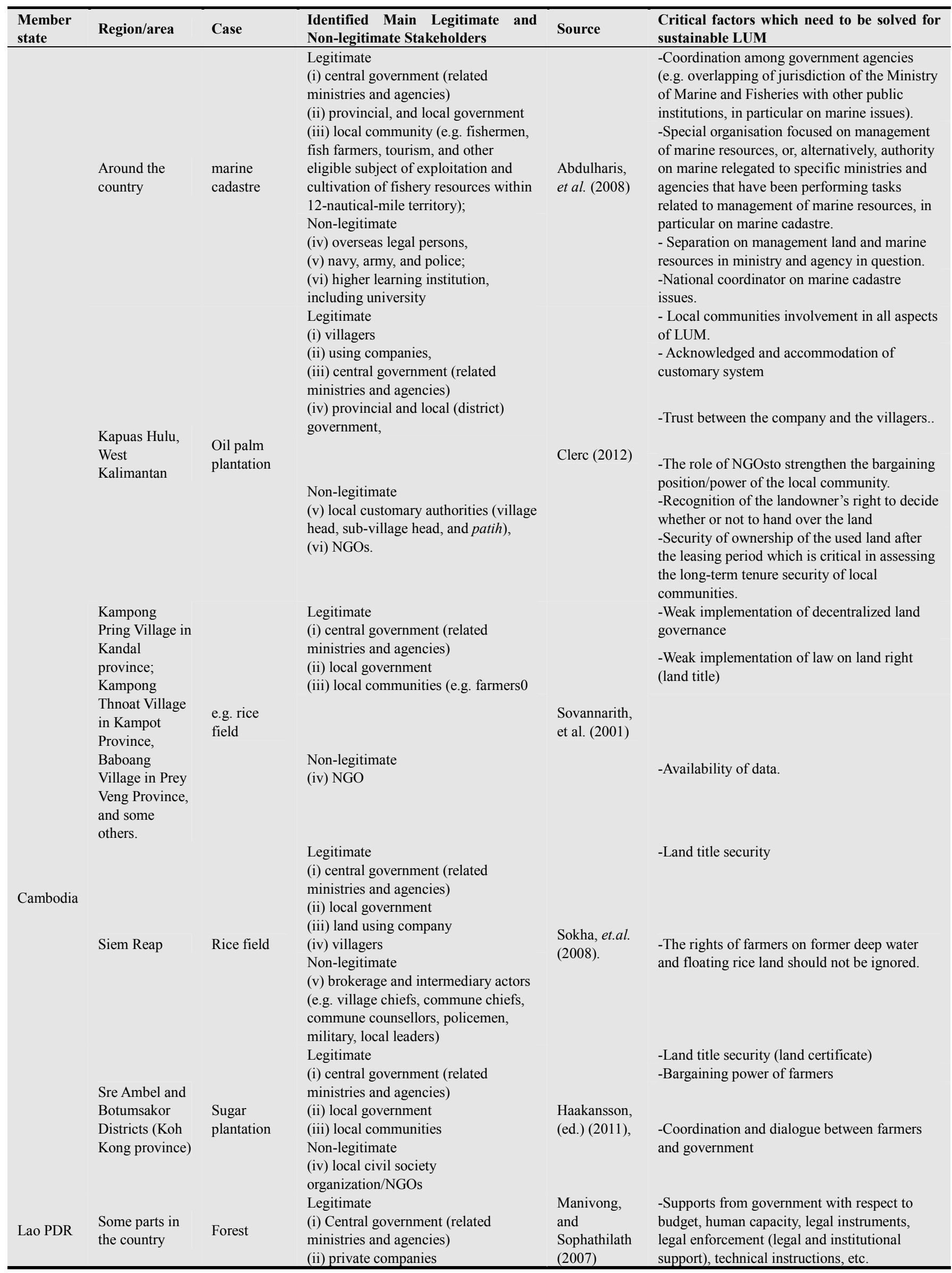




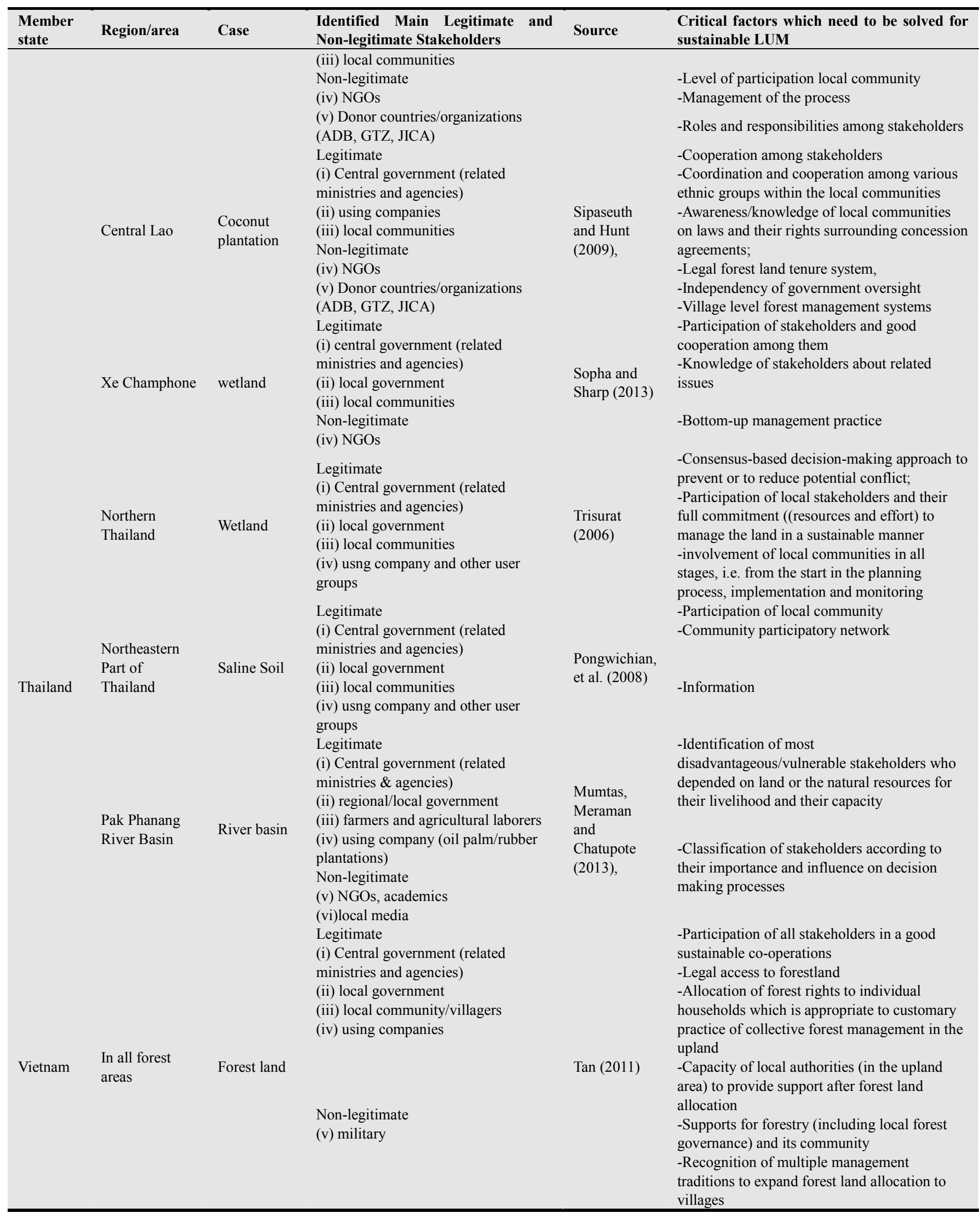

\subsection{The Overall Analysis: Common Trends, Differences and Challenges from the Country Cases}

From the above limited country studies, it reveals at least four common trends:

1) The colonial influences on the development of land tenure systems is still strong in all individual AMS; 
2) All AMS have national laws or policies on land administration and land customary rights, and the land administration systems are all decentralized, undertaken in all Municipality/Regency land offices. But these national laws on land always in conflicts with other laws (e.g. sectoral laws). Indeed, a good national coordination among government agencies/department in dealing with various issues, including land, is still lacking in most of the member states;

3) Land conflicts occur in all AMS (excluding Singapore), and the main type of land dispute has changed from disputes over boundaries to ownership rights. However, the degree (the seriousness) of the problem varies by country, depending on many factors including culture and social factors, population pressure, urbanisation process, level of economic development especially industrialization, coordination among government agencies, the strength of military influences, political system, degree of regional autonomy or centralization, degree of law enforcement, degree of violations of human rights; and4) although governments have realized the importance of the involvement of all stakeholder, in reality, the implementation with great success has been found to have occured rarely. The main constraints or the lacked supporting factors (i.e. critical factors) vary however by individual countries. For instance, in Cambodia, Lao PDR and Viet Nam, influences of local government or military officials are too strong. In the Philippines and Indonesia, law enforcement is weak and corruption is in all level of government administration is obvious.

But there are also some differences. For instance, in Myanmar, as land ultimately belongs to the state, citizens and organizations/companies do not own land; they depend upon use-rights, and tenure rights vary depending on the type of land involved. Myanmar also does not have a written policy on land use and land tenure. But, the country does have Farmland Law issued in March 2012, which defines rights and responsibilities relating to tenure and establishes a hierarchy of management over farmlands.

With respect to challenges, there are at least five challenges for having a good coordination and cooperation among all stakeholder to implement a good LUM, and the seriousness of these challenges may vary among AMS, because they are different in many issues, including demography, politic, cultural, ethnic and religious, economics, environment, climate and geography. The first challenge is related to structural factors that play a role in the process of LUM, e.g. location, the physical infrastructure, different levels of government agencies namely central government versus regional or local government agencies, competition between agencies in authority. The second challenge is linked to functional factors which include political issues inherent in the special interests of the different stakeholders that influence understanding of those diverse issues and factors that impact the process. The third challenge is about local culture, namely to have all stakeholders to sit and work together in a cooperative and fair way, especially to fully integrate individual villagers or farmers in the land use planning and LUM. Fourth, to identify the appropriate way that different stakeholders with different background influence the LUM. Fifth, to protect local community which is generally considered as the least powerful stakeholders for 'overpowered; by more powerful stakeholders (e..g big companies).

\subsection{Looking for the Best Way to Manage Land}

A good LUM consists of the following key elements. First, there should be good co-operations or interactions among stakeholders with zero conflicts. The stakeholders should be engaged from the start to enable a proactive cultivation of relationships among them. Second full integration of local community or farmers in the land use planning and LUM; they should be the engine of this integration. Third, the land should not only secure food but also generate high and sustainable production or revenues, and benefits exceed the costs of conservation, without harming the environment. Finally, the welfare or quality of life of local community or farmers should be better off.

To have a good LUM, there are a number of key preconditions. Among them is land right (or tenure) security. Land tenure security is defined as the assurance that the right holders (including the vulnerable users such as the poor and women) can exercise their right now and in the future, and be able to reap the benefits of the labor and capital invested in the resource (Nyamu-Musembi 2008; Clere, 2012). It is included in property rights security which is a critical incentive for investment in land because it guarantees the right holder will reap the benefits of their investment. Land tenure security also gives the right holder access to credit because the land can be used as collateral (Clerc, 2012). Not only crucial for securing access to food, land tenure security is related to social equity, as land tenure insecurity and land access may link to rural poverty and social position. In addition, by reducing the likelihood of competitive claims, it can decrease land-based conflicts, thus contributing to social order and peace (Clerc, 2012). Land rights security corresponds to the certainty that a right holder will not be arbitrarily deprived of his or her rights in the present or future. It depends upon a range of rights, their assurance and duration (Fuys et al. 2008).

However, land rights security alone cannot guarantee sustainable LUM, as the latter acts in a multi-level governance structure between an operational project level and a strategic level of rural/regional/national economic development management, dissolving the often occurring conflict between short-term and long-term orientation within the planning process. Here, sustainable LUM improves the coordination of economic and agricultural development policies as well as public investments and public-private investments and the involvement of inhabitants and local stakeholders in common visions. This way, LUM can be a strategic asset to allow sustainable economic growth and 
meet growing food demand. Therefore, land use planning as an instrument of LUM or rather a tool to reach the broader aim of sustainable development is concerned with the formulation of policies and plans on the use and development of land (Engelke and Biehl, 2010).

\section{Conclusion}

The above country cases have demonstrated that sustainable LUM acts in a multi-level decision processes between the lowest or micro level, i.e. an operational project level, the medium level, i.e. rural or regional economic development management, and the highest or macro level, i.e. a national economic development management. This means dissolving the often occurring conflict between short-term and long-term orientation within the planning process. Here, sustainable land use management improves the coordination of economic and agricultural development policies as well as public investments and public-private investments and the involvement of inhabitants and local stakeholders in common visions. This way, LUM can be a strategic asset to allow sustainable economic growth and meet growing food demand. Therefore, land use planning as an instrument of LUM or rather a tool to reach the broader aim of sustainable development is concerned with the formulation of policies and plans on the use and development of land.

Since LUM in general involves many stakeholders and therefore there is a need of good cooperation, there should be a body acting as the coordinator. Since the land is used for agricultural production, then the Ministry of Agriculture should focus on agricultural issues, while at the same time, acting as coordinator of stakeholders. While other stakeholders should perform their tasks in a cooperation way.

Indeed, given many stakeholders, the main challenge of LUM is to sit together and to have a smooth consultative and cooperation process, given the differences in stakeholders' interests, needs and goals to be reached, in their understandings of governance and their varying access to information. Actors from different backgrounds, such as government, civil society, academia, business, farmers and local communities rarely sit together to discuss, let alone propose solutions, governance associated challenges, although they are all affected by them.

To sum up, there are at least three most important challenges in implementing stakeholder involvement-based LUM in Indonesia and other AMS (except Singapore): (i) to have all stakeholders to sit and work together in a cooperative and fair way (ii) to identify the way and its significance that different stakeholders with different background influence the LUM; and (iii) to protect local community which is generally considered as the least powerful stakeholders for 'overpowered; by more powerful stakeholders (eg. big companies). But, in order to meet these three main challenges, some pre-conditions should be met first, and they are the critical (lacked) supporting factors as discussed before, especially, landownership or land tenure system, availability of data, law enforcement, no-corruption, and, of course, a strong political will. In many AMS, lack of these factors impedes the smooth process of LUM. Thus, to be able to meet these pre-conditions is another big challenge the countries are currently facing.

\section{References}

[1] Abdulharis, Eka Djunarsjah, and Andri Hernandi, 'Stakeholder Analysis on Implementation on Marine Cadastre in Indonesia. Integrating Generations', paper presented at the FIG Working Week 2008, 14-19 June 2008, Stockholm (Sweden).

[2] Albano, Mylene G, 'The Land Administration Reform Agenda', paper presented the International Conference on Reform in Land Administration Systems (Lessons \& Challenges), 24-26 November 2003, Makati City, Manila (Philippines).

[3] Andrianto, A., Obidzinski, K., Wajdi, F., Tetuka, B., 'Deforestation and Forest Degradation in Papua Post-New Order Regime', mimeo, Center for International Forestry Research (CIFOR) (2008), Bogor (Indonesia).

[4] Billgrena, C. and Holme, H., 'Approaching reality: Comparing stakeholder analysis and cultural theory in the context of natural resource management', Land Use Policy, 25 (2008): 550-562.

[5] Brits, Anne-Marie, Chris Grant and Tony Burns, 'Comparative Study of Land Administration Systems. With special reference to Thailand, Indonesia and Karnataka (India)', paper presented at the Regional Workshops on Land Policy Issues, Asia Program, 4-6 June 2002, Phnom Penh (Cambodia) (Land Equity International Pty Ltd - www.landequity.com.au).

[6] Clerc, Johanna, 'Unpacking tenure security', Working Paper No.102 (2012), Center for International Forestry Research, Bogor (Indonesia).

[7] Contreras-Hermosilla, A. and C. Fay, Strengthening Forest Management in Indonesia through Land Tenure Reform, Forest Trends, CIFOR (2005): Bogor (Indonesia).

[8] Dandy, N, Mark S. Reed, C. H. Quinn, H. Posthumus, C. Prell, J. Morris, K. Hubacek, A. Graves and L. C. Stringer, 'Who's in and why? A typology of stakeholder analysis methods for natural resource management,' Journal of Environmental Management, 90 (2009): 1933-1949

[9] Davuth, Lor; Suon Sopha; and Seng Thany, 'Land Administration in Cambodia', power point presentation in International Seminar on Land Administration Trends \& Issues in the Asia Pacific Region, 19-20 August 2008, Kuala Lumpur (Malaysia).

[10] Dealca, Rhea Lyn M., 'Initiatives to Improve Land Administration System in the Philippines', paper presented at the 7th FIG Regional Conference on Spatial Data Serving People: Land Governance and the Environment - Building the Capacity, 19-22 October 2009, Hanoi (Viet Nam).

[11] Ducourtieux, O., Laffort, J. R. and Sacklokham, S., 'Land policy and farming practices in Laos', Development and Change, 36(3) (2005):499-526

[12] Engelke E. D, and Dorothea Biehl, 'Land Use Management as Key Part of Metropolitan Governance for for Sustainable Urbanisation', paper presented at the 46th ISOCARP Congress 2010, Nairobi (Kenya). 
[13] FA, 'Cambodia Forestry Outlook Study', Working Paper No. APFSOS II/ WP/ 2010/ 32, Asia-Pacific Forestry Sector Outlook Study II, the Forestry Administration, Phnom Penh (Cambodia).

[14] FAO, 'Conflict and Natural Resource Management', Community Forestry, 2000, June, Roma.

[15] Fujita, Y., Vongvisouk, T., Chantavong, H. and Chanthaleunnavong, S., 'Decentralized forest management in production forest in Central Laos Forest, Dong Phousi Production Forest and Dong Sithuoane Production Forest', in P. Durst, C. Brown, H. D. Tacio and M. Ishikawa (eds.), In Search of Excellence: Exemplary Forest Management in Asia and the Pacific (2005), Food and Agriculture Organization of the United Nations, Regional Office for Asia and the Pacific, and the Regional Community Forestry Training Center for Asia and the Pacific (RECOFTC), Bangkok (Thailand).

[16] Fuys, A., Mwangi, E. and Dohrn, S., 'Securing common property regimes in a globalizing world. Synthesis of 41 case studies on common property regimes from Asia, Africa, Europe and Latin America', CGIAR System wide Program on Collective Action and Property Rights (2008), Rome (Italy): International Land Coalition (http://dlc.dlib.indiana.edu/dlc/bitstream/handle/10535/5363/IL C_ Securing_Common_ Property_ Regimes_E.pdf? sequence $=\overline{1}$ ).

[17] Grimble, R., 'Stakeholder methodologies in natural resource management, Socioeconomic Methodologies', Research Report (1998), Chatham (England): Natural Resources Institute.

[18] Grimble, R. and Wellard, K., 'Stakeholder methodologies in natural resource management: a review of principles, contexts, experiences and opportunities', Agricultural Systems, 55(2) (1997): 173-193

[19] Guiang, Ernesto S. and Gem Castillo, 'Trends in Forest Ownership, Forest Resources Tenure and Institutional Arrangements in the Philippines: Are They Contributing to Better Forest Management and Poverty Reduction?', paper prepared for FAO as one of a series of country-specific case studies from Asia, Manila: Philippine Environmental Governance Project Phase 2 (EcoGov 2), the United States Agency for International Development (USAID), Development Alternatives Inc. (DAI), and the Philippines Department of Environment and Natural Resources (DENR) (2006), Manila (the Philippines).

[20] Haakansson, Malene (ed.), 'Stolen Land Stolen Future. A Report on Land Grabbing in Cambodia', Association of World Council of Churches related Development Organisations in Europe (APRODEV), December 2011, Brussel (Belgium).

[21] IFC, 'Stakeholder Engagement: A Good Practice Handbook for Companies Doing Business in Emerging Markets', May 2007, Washington, D. C. (the United States): International Finance Corporation

[22] Kayoi, Martin, Adrian Wells, and Gill Shepherd, 'Poverty and Natural Resource Conflict in Indonesian Papua: Reconciling Growth and Social Justice', research paper, September 2006, http://www.profor.info/Documents/pdf/livelihoods/IndonesianP apuaCaseStudy.pdf, Jakarta (Indonesia).

[23] Larsen, Rasmus Klocker, Jo Marie Acebes, and Alejandro Belen, ' Philippines Integrated Coastal Management: diverging Stakeholder Agendas and Elite Co-option in the Babuyan Islands', Working Paper, October 2010, Stockholm (Sweden): Stockholm Environment Institute
[24] Manivong, Khamphay and Phouthone Sophathilath, 'Status of Community Based Forest Management in Lao PDR', January 2007, Bangkok (Thailand) and Vientiane (Lao PDR): The Regional Community Forestry Training Center for Asia and the Pacific (RECOFTC) and National Agriculture and Forestry Institute (NAFRI), Ministry of Agriculture and Forestry.

[25] MK16 Project Team,'Fostering Evidence-Based IWRM in the Stung Pursat Catchment (Tonle Sap Great Lake) Cambodia CPWF-Mekong Basin Development Challenge. Stakeholder Analysis Report', prepared for Mekong Basin Leader CGIAR Challenge Program on Water and Food, March 2013, North Vancouver, British Columbia, Canada,.

[26] Mumtas, Meraman and Chatupote, 'Stakeholder Analysis for Sustainable Land Management of Pak Phanang River Basin, Thailand', Procedia-Social and Behavioral Sciences, 91 (2013): 349-356.

[27] Natalie Bugalski and David Pred (eds.), 'Untitled. Tenure Insecurity and Inequality in the Cambodian Land Sector', (2009) Bridges Across Borders Southeast Asia, Centre on Housing Rights and Evictions, Jesuit Refugee Service, Phnom Penh (Cambodia)

[28] Nyamu-Musembi, C., Breathing life into dead theories about property rights in rural Africa, lessons from Kenya', in B. Englert and E. Daley (eds.), Women's land rights and privatization in Eastern Africa, (2008) Oxford (UK): James Currey.

[29] Phillips, Robert, 'Some Key Questions About Stakeholder Theory', Ivey Business Journal, March/April 2004 (http:.//iveybusinessjournal.com/topics/the-workplace)

[30] Pongwichian, Pirach, Chaiyanam Dissataporn and Kulras Ananpongsuk, 'Community Participatory Network on Sustainable Land Management: A Case Study on Saline Soil in Northeastern Part of Thailand', (2008) Office of Research and Development for Land Management, LDD, Bangkok (Thailand) (http://www.ldd.go.th/web_LDDAPEC/PDF/30/30nov_10\%20 Pirach\%20Community\%20Participatory\%20Network.pdf).

[31] Prell, C., K. Hubacek, M. S. Reed, T. P. Burt, J. Holden, N. Jin, 'Stakeholder Analysis and Social Network Analysis in Natural Resource Management', (2007) Leeds (United Kingdom), Sustainability Research Institute, University of Leeds.

[32] REDD, 'Laos', REDD Countries, the REDD Desk, 04/07/2012, Vientiane

(Laos), (http://theredddesk.org/sites/default/files/resources/countries/rea diness_overview/laos ro en.pdf).

[33] Sawathvong, Silavanh, Participatory Land Management Planning in Biodiversity Conservation Areas of Lao PDR, Doctoral thesis (2003), Department of Forest Resource Management and Geomatics, Swedish University of Agricultural Sciences, Uppsala, Sweden.

[34] Sawathvong, Silivanh, 'Experiences from developing an integrated landuse planning approach for protected areas in the Lao PDR', Forest Policy and Economics 6 (2004): 553-566, Vientiane (Lao PDR) (http://www.elseveier. com/ locate/ forpol).

[35] Sipaseuth, Phetdavan and Glenn Hunt, 'Customary Land Rights in Laos - an overview', power point presentation (2009), JVC Laos, Vientiane (Lao PDR).

[36] Sirait, M. T., 'Indigenous peoples and oil palm plantation expansion in West Kalimantan, Indonesia', research paper (2009), Amsterdam University Law Faculty and Cordaid, Amsterdam \& The Hague (the Netherlands). 
[37] Sokha, Pel, Pierre-Yves Le Meur, Sam Vitou, Laing Lan, Pel Setha, Hay Leakhena and Im Sothy, 'Land Transactions in Rural Cambodia. A Synthesis of Findings from Research on Appropriation and Derived Rights to Land', Gret Collection Études et Travaux - Série en ligne ${ }^{\circ} 18$, May 2008, Phnom Penh (Cambodia): GRET Organisation (www.gret.org).

[38] Samsudin, Salfarina, 'A Review of Organizational Arrangements in Malaysia Land Administration System towards Good Governance: Issues and Challenges', paper presented at the FIG Working Week 2011, 18-22 May 2011, Bridging the Gap between Cultures, Marrakech (Morocco).

[39] Sar, Sovann, 'Land Reform in Cambodia', paper presented at the FIG Congress 2010 'Facing the Challenges - Building the Capacity', 11-16 April 2010, Sydney (Australia),

[40] Sopha, Thienthong and Alice Sharp, ' Sustainable Wetland Management in Lao PDR: A Case Study of Xe Champhone Wetlands', paper presented at the 3rd International Conference on Ecological, Environmental and Biological Sciences (ICEEBS'2013), 29-30 April 2013, Singapore.

[41] Sovannarith, So, Real Sopheap, Uch Utey, Sy Rathmony Brett Ballard and Sarthi Acharya, 'Social Assessment of Land in Cambodia. A Field Study', Working Paper No. 20, November 2001, Cambodia Development Resource Institute, Phnom Penh (Cambodia).

[42] UNDP, 'Participatory Governance Assessment: The 2012 Indonesia Forest, Land, and REDD+ Governance Index', UNREDD Programme (2013), Jakarta (Indonesia).
[43] USAID, 'Thailand', USAID Country Profile 2013, Property Rights and Resource Governance, Washington, DC (the USA) (http://usaidlandtenure.net/Burma).

[44] USAID, 'Burma', USAID Country Profile 2013, Property Rights and Resource Governance, Washington, DC (the USA) (http://usaidlandtenure.net/Burma).

[45] Tan, Nguyen Quang, 'Forest Land Allocation and Community Forest Management in Vietnam', Session J, 13 July 2011, RECOFTC - The Center for People and Forests, Lombok (Indonesia).

[46] Thongmanivong, S. and Fujita, Y., 'Recent land use and livelihood transition in Northern Laos', Mountain Research and Development, 26(3) (2006):237-244

[47] Thongmanivong, S., Fujita, Y. and Fox, J., 'Resource use dynamics and land-cover change in Ang Nhai Village and Phou Phanang National Reserve Forest, Lao PDR', Environmental Management, 36(3): (2005) 382-393

[48] Trisurat, Yongyut,'Community-based Wetland Management in Northern Thailand', International Journal of Environmental, Cultural, Economic and Social Sustainability, 2(1) (2006):4962.

[49] Wells-Dang, Andrew, 'Promoting Land Rights in Vietnam: A Multi-Sector Advocacy Coalition Approach', Annual World Bank Conference on Land and Poverty, 8-11 April 2013, The World Bank, Washington DC (the USA). 